\title{
Distribution of adsorbed ammonium pools in two intertidal sedimentary structures, Marennes-Oléron Bay, France
}

\author{
M. J. C. Laima ${ }^{1, *}$, M. F. Girard ${ }^{2}$, F. Vouvé ${ }^{2}$, G. F. Blanchard ${ }^{2}$, D. Gouleau ${ }^{2}$, R. Galois ${ }^{2}$, \\ P. Richard ${ }^{2}$
}

${ }^{1}$ University of Aarhus, Department of Earth Sciences, Ny Munkegade, Building 520, DK-8000 Aarhus C, Denmark

${ }^{2}$ CREMA, CNRS-IFREMER, Place du Seninaire, BP 5, F-17137 L'Houmeau, France

\begin{abstract}
The 1-step and multiple-step $\mathrm{KCl}$ extraction technique was used to evaluate quantitatively the distribution of adsorbed $\mathrm{NH}_{4}{ }^{+}$in the $0-5 \mathrm{~cm}$ strata of 2 intertidal muddy structures from Marennes-Oléron Bay, France. $\mathrm{KCl}$ extraction efficiency was higher in the reconstituted sediment slurries and decreased significantly in the presence of porewater ions, leading to underestimations of the size of the pool of adsorbed, easily desorbed $\mathrm{NH}_{4}{ }^{+}$Various pools of adsorbed $\mathrm{NH}_{4}{ }^{+}$were displaced from the sediment after reaction with $\mathrm{KCl}$ in multiple steps. Pools of tightly bound $\mathrm{NH}_{4}{ }^{+}$were much larger in runnels as opposed to ridges, and accounted for up to $32 \%$ (ridge) and $40 \%$ (runnel) of the $\mathrm{NH}_{4}{ }^{+}$desorbed from the sediment. These pools have important implications for the calculation of the $K_{D}$ value, the dimensionless $\mathrm{NH}_{4}{ }^{+}$distribution coefficient. Differing relationships between easily desorbed $\mathrm{NH}_{4}{ }^{+}$ or tightly bound $\mathrm{NH}_{4}{ }^{4}$, on the one hand, and the sediment grain size, $\mathrm{CaCO}_{3}$ and $\mathrm{N}$ content, on the other, suggest multiple origins for particulate matter in the sediment.
\end{abstract}

KEY WORDS: Ammonium Adsorption $\cdot$ Mudflat $\cdot$ Ridge $\cdot$ Runnel

\section{INTRODUCTION}

An important fraction of the organic matter produced in coastal ecosystems is deposited and decomposed in sediments. Ammonium, which is regenerated by deamination of this organic matter, can be found dissolved in pore water, adsorbed onto the surface of clay particles and organic matter, or fixed within the clay structure. There is a dynamic equilibrium between $\mathrm{NH}_{4}{ }^{+}$pools and, in addition, there is a rapid exchange between the adsorbed pool and the porewater pool. Ammonium which is not nitrified in the oxic layers of sediment is ultimately released to the overlying water and may influence primary production (Boynton et al. 1982). As the adsorbed pool may represent a substantial part of total $\mathrm{NH}_{4}{ }^{+}$in sediments, the adsorption process must be considered when model-

·E-mail: geomario@aau.dk ling nitrogen diagenesis in coastal sediments (Rosenfeld 1979). Indeed, Berner $(1976,1977)$ established the importance of including an adsorption term in his stoichiometric model of nitrogen regeneration, and Blackburn (1980) showed that the assessment of this exchangeable $\mathrm{NH}_{4}{ }^{+}$is necessary for studying nitrogen turnover.

The assessment of adsorbed $\mathrm{NH}_{4}{ }^{+}$is usually achieved through $\mathrm{KCl}$ extraction, but Laima $(1992 b, c)$ has shown that a 1-step procedure protocol is not sufficient to release the total adsorbed pool and that it is necessary to proceed through a multiple $\mathrm{KCl}$ extraction method of up to 6 or 7 successive steps. Thus, he found that 1 -step extractions removed only 29 to $77 \%$ of the total adsorbed $\mathrm{NH}_{4}{ }^{+}$pool, depending on the sediment type and season. This 'tightly bound $\mathrm{NH}_{4}{ }^{+}$' (the sum of additional $\mathrm{KCl}$ extractions), as opposed to the 'easily exchangeable $\mathrm{NH}_{4}{ }^{+*}$ fraction (the amount released by a 1-step $\mathrm{KCl}$ extraction minus porewater $\mathrm{NH}_{4}^{+}$), can 
represent the dominant form of $\mathrm{NH}_{4}{ }^{+}$and may strongly influence the calculation of the sediment exchange capacity and the $\mathrm{NH}_{4}^{+}$ turnover rate. Therefore, it is of prime importance to assess this pool quantitatively and to appraise the effect of the factors controlling it.

Intertidal mudflats are areas of intensive organic matter production and deposition, and thus also of mineralization. These mudflats play an important role in benthic regeneration in estuaries and associated bays. Although their importance in primary productivity (Pinckney \& Zingmark 1993) and as a food source for benthic invertebrates (Montagna et al. 1995, Riera el al. 1996) has been recognized, their role in the whole ecosystem is not fully understood. Such mudflats are frequently characterized by major sedimentary structures known as 'ridges and runnels', i.e. a parallel succession of crests and troughs normal to the shore (Dyer 1998). These features are likely to act as a prominent structuring spatial factor, however, and their influence on the distribution of most geochemical and biological variables is still unknown.

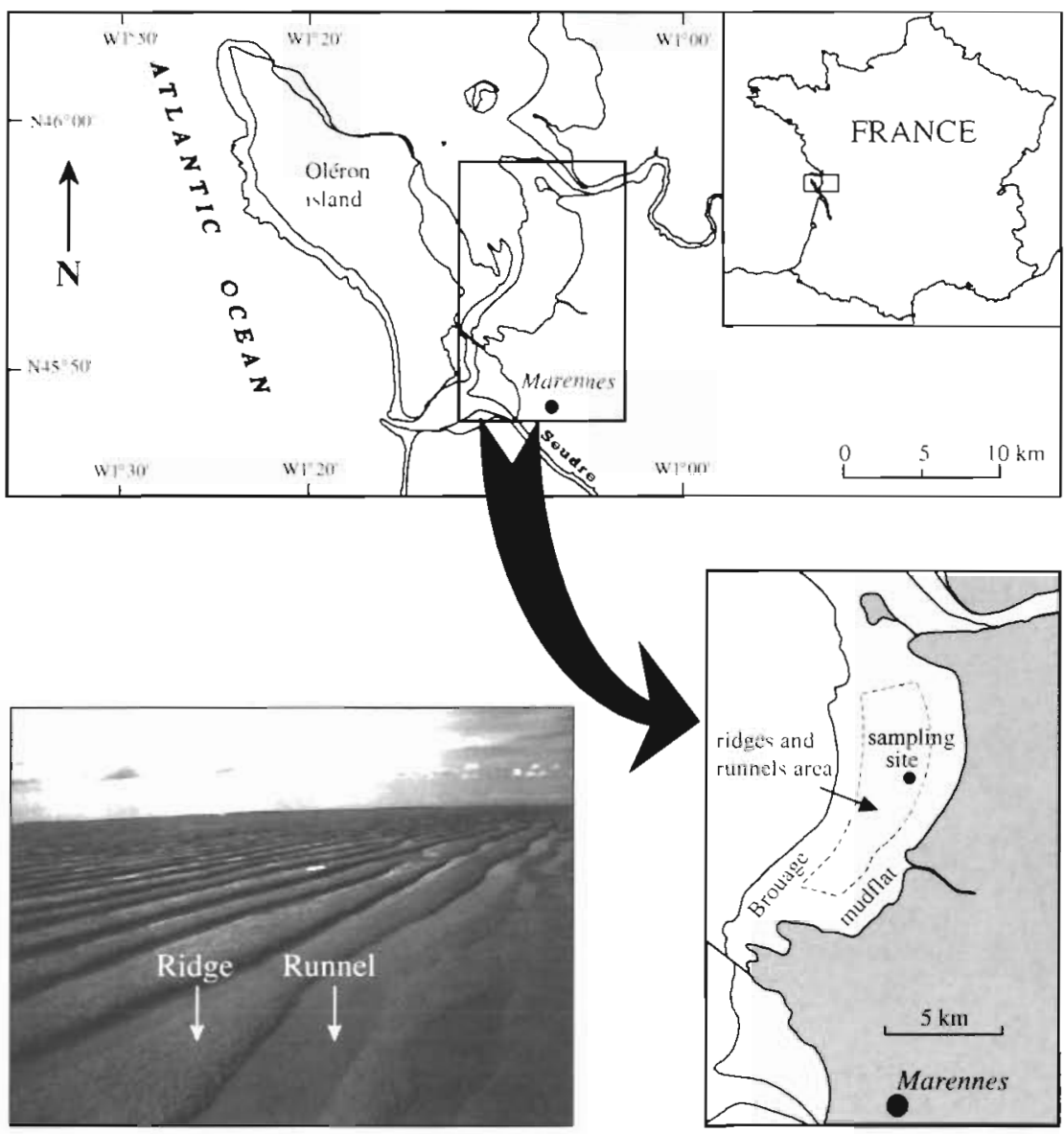

Fig. 1. Photograph of ridges and runnels at the study site, and maps showing the site location in the middle of an intertidal mudflat in Marennes-Oleron Bay, France

It is therefore our goal (1) to test the methodology for the measurement of the different adsorbed $\mathrm{NH}_{4}{ }^{+}$pools and (2) to show that the 'ridges and runnels' structures strongly influence the distribution of sediment ammonium pools and the efficiency of ammonium extractability. Finally, we shall provide a budget of ammonium distribution as a function of these intertidal sedimentary structures.

\section{MATERIALS AND METHODS}

Study area. Marennes-Oléron Bay is an estuarine zone occupying an area of about $170 \mathrm{~km}^{2}$ between Aix Island and the Maumusson Channel in south-west France (Fig. 1). Bedforms extend over most of the mudflat, and they represent permanent structures in which ridges occupy $2 / 3$ and and runnels $1 / 3$ of the surface area (Sauriau et al. 1997). There is a major contribution of autochthonous material to the sediments, essentially composed of microphytobenthos (Cariou-Le Gall \& Blanchard 1995), of which the most abundant are diatoms (particularly Navicula, Nitzschia and Gyrosigma). Macrofauna assemblages on Brouage mudflats belong to the Macoma balthica community (Thorson 1957). However, there is some difference between the species abundances on ridges and runnels (Sauriau \& Gouleau unpubl. data). Thus, Hydrobia ulvae is more numerous in the runnels. This is a surface and/or a subsurface deposit feeder that can easily crawl on and dig into the fluid mud of runnels. In contrast, Scrobicularia plana, a deposit-feeder, is more numerous on ridges: its biomass can be over $30 \mathrm{~g}$ ash-free dry weight (AFDW) $\mathrm{m}^{-2}$. Polychaetes species are also more numerous in ridges as against runnels. Tubificoides benedeni, Tharyx marioni, Streblospio shrubsolii benefit from the more stable conditions on the rigdes compared to runnels. $M$. balthica, a suspension/deposit-feeder bivalve, and Nereis ombergii, a carnivorous polychaete, are equally distributed over both bedforms. The hydrobiological. characteristics of the bay have been described elsewhere (Héral et al. 1983). Recent work has studied the role of the microtopography on diffusive $\mathrm{NH}_{4}^{+}$and $\mathrm{NO}_{3}^{-}$fluxes (Gouleau 
unpubl. data) and on its ability to trap nutrients and to regulate geochemical fluxes (Feuillet-Girard et al. 1988, 1997)

Sampling protocol and extraction procedures. Sampling took place in the upper part of the middle slikke where the ridge-and-runnel system spreads over a $30 \mathrm{~km}^{2}$ area of the mudflat, see Fig. 1 and Germaneau \& Sauriau (1996). Twelve sediment cores $(5.4 \mathrm{~cm}$ diam., $20 \mathrm{~cm}$ long) were collected randomly by hand at low tide (tidal coefficient $=36$ ) on April 16, 1997, 6 covering about $3 \mathrm{~m}^{2}$ of surface area on a ridge and similarly a further 6 in an adjacent runnel. Based on previous tests on site variability of porewater nutrient concentration, this sampling strategy was found to give a good representation of the study area (Feuillet-Girard unpubl, data). Sediment cores were stored at $0^{\circ} \mathrm{C}$ and quickly transported to the laboratory. Overlying water was carefully discarded, the sediment was then cut into five $1 \mathrm{~cm}$ thick slices. Samples were sieved through a $1.5 \mathrm{~mm}$ mesh to remove gross detritus and macrofauna. Specific density was measured gravimetrically in triplicate. A portion of wet sediment was sieved ( $50 \mu \mathrm{m}$ mesh); some coarse fraction was used for grain size determinations and some was dried and decarbonated with $\mathrm{HCl}$ for the determination of the $\mathrm{CaCO}_{3}$ content. Water content was measured as weight loss after drying for $72 \mathrm{~h}$ at $60^{\circ} \mathrm{C}$ and corrected for salt effects. The C-N composition of sediment organic matter was determined in duplicate using a CHN analyzer Carlo Erba 1500 using acetanilide $(\mathrm{N}=10.39 \%$ and $\mathrm{C}=71.09 \%$ ) as standard. Prior to the $\mathrm{C}-\mathrm{N}$ analysis, $100 \mathrm{mg}$ of sediment were acidified with $\mathrm{HCl} 1 \mathrm{~N}$ to remove carbonates. This decarbonatation was increased by sonification. Then the samples were dried under vacum to eliminate $\mathrm{HCl}$ vapours, after which $1 \mathrm{ml}$ of Milli-Q $\mathrm{H}_{2} \mathrm{O}$ was added and the samples were homogenized by sonification and freeze-dried.

Some sediment characteristics are shown in Table 1.
Collection of porewater and $\mathrm{KCl}$ extracts. Moderate to intensive extraction assays were designed to point out the likely effect of porewater ions on $\mathrm{KCl}$ efficiency for displacement of $\mathrm{NH}_{4}{ }^{+}$from the sediment, and to desorb at least 3 exchangeable $\mathrm{NH}_{4}{ }^{+}$pools. In Series A. (Fig. 2, left-hand side) slices from different depths were purged in $\mathrm{N}_{2}$ and centrifuged in gas-tight containers. Porewater extracts were filtered through GF/C Whatman filters $(0.45 \mu \mathrm{m}$ pore size), and stored at $-20^{\circ} \mathrm{C}$ for further treatment. Sediment pellets from which pore water had been removed (about $30 \%$ remained) were mixed together with de-ionized $\mathrm{H}_{2} \mathrm{O}$ in a double wash, and left on ice. The suspension was centrifuged and $\mathrm{NH}_{4}{ }^{+}$was measured in the supernatant. This procedure was repeated until the $\mathrm{NH}_{4}{ }^{+}$ concentration in the supernatant was below 5 umol $\mathrm{l}^{-1}$. When necessary, de-ionized $\mathrm{H}_{2} \mathrm{O}$ was added to these pellets to regain the original $\mathrm{H}_{2} \mathrm{O}$ content. Reconstituted sediments were pooled and extracted at $0^{\circ} \mathrm{C}$ with $2 \mathrm{M} \mathrm{KCl}$ which was bubbled with pure $\mathrm{N}_{2}$ immediately before use (Laima 1994). In Series B (Fig. 2, right-hand side), slices from each level were pooled together, and $\mathrm{KCl}$ extracts incorporating both pore water and the easily desorbed pool were obtained as before. Finally, pellets were weighed and new equivalent amounts of $\mathrm{KCl}$ were added, always keeping the sediment to extractant ratio constant. Multiple extractions were carried out until 6 additional supernatants were obtained from each depth.

Analyses and calculations. Salinity was measured using a microprocessor conductivity meter LF 320 WTW and a standard conductivity cell Tetracon 325. Ammonium was measured using the salicylate method with minor modifications (Laima 1992a). Reagents were added to 10 - to 20 -fold diluted water samples, and absorbance units (AU) were read in a Uvikon 722 LC spectrophotometer fitted with a quartz halogen

Table 1. Some characteristics of ridge and runnel structures. Marennes-Oléron Bay, April 1997

\begin{tabular}{|c|c|c|c|c|c|c|c|}
\hline $\begin{array}{l}\text { Layer } \\
(\mathrm{cm})\end{array}$ & $\begin{array}{c}\mathrm{H}_{2} \mathrm{O} \\
\left(\mathrm{ml} \mathrm{g}^{-1}\right)\end{array}$ & $\begin{array}{l}\text { Porosity } \\
\left.(\mathrm{ml} \mathrm{cm})^{-3}\right)\end{array}$ & $\underset{(\%) \mid}{\text { Salinity }}$ & $\stackrel{\mathrm{N}}{\left(\mu \mathrm{g} \mathrm{mg}^{-1} \mathrm{dw}\right)}$ & $\frac{C}{\left(\mu g \mathrm{mg}^{-1} \mathrm{dw}\right)}$ & $\begin{array}{c}\text { Grain }>50 \mu \mathrm{m} \\
(\%)\end{array}$ & $\begin{array}{c}\mathrm{CaCO}_{3}{ }^{b} \\
(\%)\end{array}$ \\
\hline \multicolumn{8}{|c|}{ Ridges } \\
\hline $0-1$ & 0.57 & 0.71 & 44.7 & 1.7 & 11.5 & 1.9 & 21.3 \\
\hline $1-2$ & 0.51 & 0.58 & 45.0 & 1.6 & 10.8 & 4.3 & 16.9 \\
\hline $2-3$ & 0.49 & 0.61 & 40.0 & 1.6 & 10.6 & 4.7 & 15.1 \\
\hline $3-4$ & 0.54 & 0.68 & 39.0 & 2.0 & 12.6 & 2.2 & 16.9 \\
\hline $4-5$ & 0.56 & 0.70 & 37.7 & 1.6 & 10.7 & 1.9 & 25.5 \\
\hline \multicolumn{8}{|c|}{ Runnels } \\
\hline $0-1$ & 0.66 & 0.81 & 35.3 & 1.7 & 12.0 & 1.9 & 48.9 \\
\hline $1-2$ & 0.66 & 0.85 & 35.7 & 1.9 & 14.2 & 2.8 & 55.8 \\
\hline $2-3$ & 0.62 & 0.79 & 35.3 & 2.2 & 15.2 & 1.8 & 59.1 \\
\hline $3-4$ & 0.61 & 0.80 & 35.0 & 2.1 & 12.8 & 1.9 & 53.7 \\
\hline $4-5$ & 0.60 & 0.80 & 32.8 & 1.8 & 12.1 & 5.6 & 39.8 \\
\hline
\end{tabular}




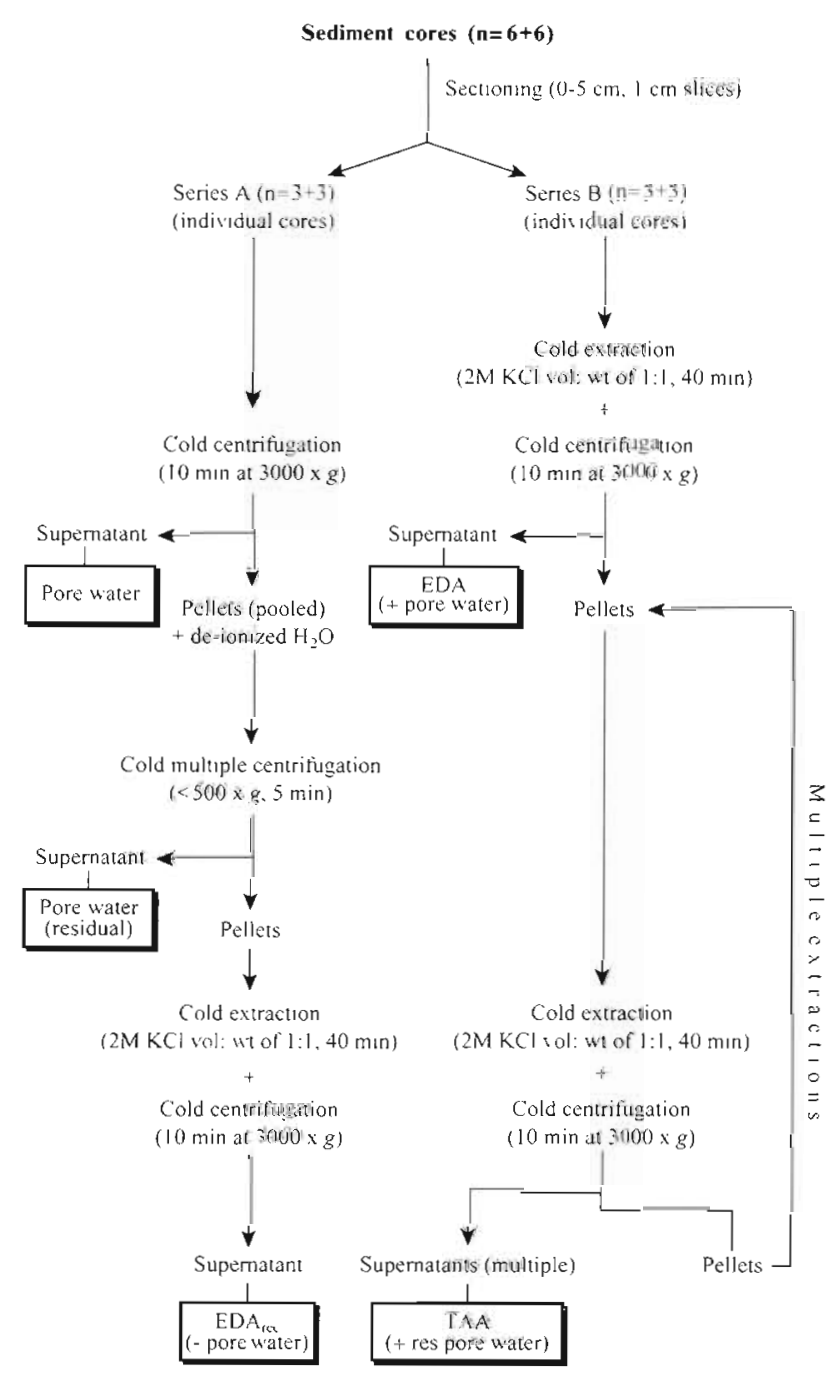

Fig. 2. Extraction scheme for removal of porewater, easily desorbed $\mathrm{NH}_{4}{ }^{+}$(EDA), reconstituted. EDA (EDA rec) and tightly adsorbed ammonium (TAA) pools. All steps were performed under a stream of $\mathrm{N}_{2}$

lamp and a R 928 PM detector. Detection limits lie in the -0.3 to $4 \mathrm{AU}$ range, the photometric accuracy is better than $\pm 0.004 \mathrm{AU}$ at $1 \mathrm{AU}$. Unknown factors present in extracts from marine sediments are known to interfere with colour development of the salicylate method (Ngo et al. 1982). We tested these effects by calculating $\mathrm{NH}_{4}{ }^{+}$recovery in 10 - to 20 -fold diluted samples that were spiked with internal standards. A good recovery ( $99 \%$ ) was obtained, so possible interfering factors on colour development were absent in the used dilution range. Adsorbed, easily desorbed $\mathrm{NH}_{4}{ }^{*}$ (EDA) is the pool desorbed in the normal 1-step extraction of fresh sediment (Series B), minus the $\mathrm{NH}_{4}{ }^{+}$ dissolved in pore water. Reconstituted, easily desorbed $\mathrm{NH}_{4}{ }^{+}\left(\mathrm{EDA}_{\text {rec }}\right)$, is the fraction desorbed after 1-step $\mathrm{KCl}$ extraction of reconstituted sediment (Series A). Total adsorbed $\mathrm{NH}_{4}{ }^{+}$is obtained by substracting porewater $\mathrm{NH}_{4}{ }^{+}$(as measured in Series A) from the total $\mathrm{NH}_{4}{ }^{+}$in multiple $\mathrm{KCl}$ extractions (Series $\mathrm{B}$ ), after correction for residual pore water and residual $\mathrm{KCl}$. Tightly adsorbed ammonium (TAA) is obtained by subtracting the EDA pool from the pool desorbed in 6 residual extractions. Analyses of variance and correlation analysis at $95 \%$ confidence interval were performed using STATISTICA (StatSoft Inc. 1993).

\section{RESULTS AND DISCUSSION}

Pool sizes of easily desorbed $\mathrm{NH}_{4}{ }^{+}$depended on whether or not pore water had been removed prior to addition of $\mathrm{KCl}$. Fig. 3 shows relationships between EDA and $E A_{\text {rec }}$ in the $0-5 \mathrm{~cm}$ strata of ridges and runnels. In both structures, measurements of the reconstituted pool yielded more $\mathrm{NH}_{4}{ }^{+}$compared to the original pool. It is not likely that the higher $\mathrm{NH}_{4}{ }^{+}$ yield found in $E D A_{\text {rec }}$ is due to exposure of new organic binding sites to added $\mathrm{K}^{+}$since we did not observe more coloured waters in these rinses. An explanation for a lower $\mathrm{NH}_{4}{ }^{+}$yield in EDA compared to $E D A_{\text {rec }}$ is a $K^{+}$effect in the presence of porewater (pw) ions, in moving the equilibrium $\mathrm{NH}_{4}{ }^{+}$pw $\mathrm{NH}_{4}{ }^{+}$ exch towards sites with poor access to cation exchange (exch). Depressive effects of $\mathrm{K}^{+}$on $\mathrm{NH}_{4}{ }^{+}$exchange have also been reported in other coastal environments (Laima 1994) and in soil studies (Nômmik \& Vahtras 1982). This hypothesis is further supported by Fig. 4 , where cumulative $\mathrm{NH}_{4}{ }^{+}$concentration data obtained from multiple extractions of intact sediments (pore water included) are plotted against the number of

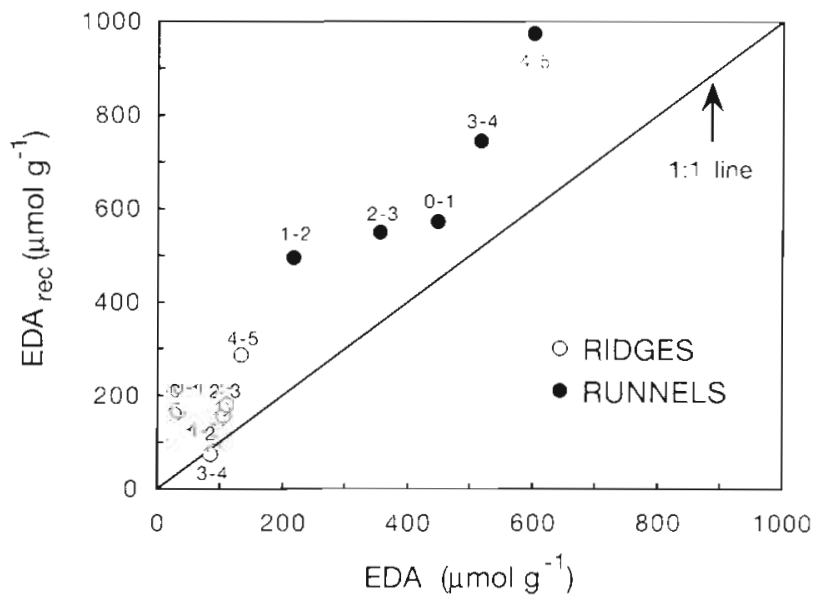

Fig. 3. Effect of the extraction procedure on the measurement of the EDA pool 
Table 2. Average distribution of $\mathrm{NH}_{4}{ }^{+}$pools in the $0-5 \mathrm{~cm}$ strata of ridge and runnel structures and linear relationships between dissolved and adsorbed $\mathrm{NH}_{4}{ }^{+}$

\begin{tabular}{|c|c|c|c|c|}
\hline & $\begin{array}{c}\mathrm{NH}_{4}^{+} \\
\left(\mathrm{nmol} \mathrm{g}^{-1}\right)\end{array}$ & $\begin{array}{c}\mathrm{NH}_{4}{ }^{+} \\
(\% \text { total })\end{array}$ & $\begin{array}{l}\text { Linear regression } \\
\qquad\left(\mathrm{r}^{2}\right)\end{array}$ & $p$ \\
\hline \multicolumn{5}{|l|}{ Ridges } \\
\hline \multicolumn{5}{|l|}{ Pools } \\
\hline Pore water & 51 & 22 & & \\
\hline $\mathrm{EDA}_{\text {iec }}(1$-step $\mathrm{KCl}$ extraction $)$ & 108 & 46 & & \\
\hline TAA (6 extra $\mathrm{KCl}$ extractions) & 74 & 32 & & \\
\hline Total extractable pool & 233 & 100 & & \\
\hline \multicolumn{5}{|l|}{ Relationships } \\
\hline Pore water vs EDA $A_{\text {rec }}(n=20)$ & & & 0.92 & $<0.05$ \\
\hline Pore water vs TAA $(n=20)$ & & & 0.73 & $>0.05$ \\
\hline \multicolumn{5}{|l|}{ Runnels } \\
\hline \multicolumn{5}{|l|}{ Pools } \\
\hline Pore water & 80 & 7 & & \\
\hline $\mathrm{EDA}_{\text {rer }}(1$-step $\mathrm{KCl}$ extraction) & 587 & 53 & & \\
\hline TAA (6 extra $\mathrm{KCl}$ extractions) & 447 & 40 & & \\
\hline Total extractable pool & 1114 & 100 & & \\
\hline \multicolumn{5}{|l|}{ Relationships } \\
\hline Pore water vs $\operatorname{EDA}_{\text {rec }}(n=20)$ & & & 0.17 & $>0.05$ \\
\hline Pore water vs TAA $(n=20)$ & & & 0.09 & $>0.05$ \\
\hline
\end{tabular}

The dimensionless $\mathrm{NH}_{4}{ }^{+}$distribution coefficient $K_{\mathrm{D}}$ is calculated as (Krom \& Berner 1980)

$$
K_{\mathrm{D}}=(1-\Phi / \Phi) p_{s} K^{\cdot}
$$

where $\Phi$ is porosity (porewater volume/sediment volume), $p_{\mathrm{s}}$ is dry sediment density (assumed $2.65 \mathrm{~g} \mathrm{ml}^{-1}$ ) and $K^{*}=C^{*}{ }_{N} / C_{N}$, where $C^{*}{ }_{N}$ is the rapidly exchangeable $\mathrm{NH}_{4}{ }^{+}$concentration in $\mu \mathrm{mol} \mathrm{g}{ }^{-1}$ dry $w \mathrm{t}$ sediment and $C_{N}$ is the porewater concentration in $\mathrm{mM}$ relative to porewater volume. Usually, $K_{\mathrm{D}}$ values range from 1 to 20 in marine sediments (Seitzinger et al. 1991, Raaphorst \& Malschaert 1996). The term $C^{*}$ in Eq. (1) was improved to account for the multiple-extractable pool. The adsorbed pool obtained in this way undoubtedly gives a better estimate of this coefficient (Table 2) and therefore should be used in models of $\mathrm{NH}_{4}{ }^{+}$adsorption (Boatman \& Murray 1982).

extractions. Extraction of $\mathrm{NH}_{4}{ }^{+}$increased initially, following a progressive dilution of the porewater pool and a simuitaneous increase of excess $\mathrm{K}^{+}$concentration. However, if the $\mathrm{NH}_{4}{ }^{+}$yield were only a result of volumetric effects, dilution curves would be comparable. This was not the case. It is more likely that $\mathrm{NH}_{4}{ }^{+}$, which moved towards non-exchangeable pools during the first extraction step, had re-entered the exchangeable pool. The decrease in yield during the remaining extractions was probably caused by exhaustion of $\mathrm{NH}_{4}{ }^{+}$adsorbed to the sediment matrix. It is clear that the TAA pool represented a substantial fraction of $\mathrm{NH}_{4}{ }^{+}$in these intertidal sediments: $32 \%$ in ridges and $40 \%$ in runnels (Table 2 ).

Differences between ridges and runnels were also found in the porewater $\mathrm{NH}_{4}{ }^{+}$distribution along the sedimentary profile (Table 3 ). Variation among cores was high (CV up to $56 \%$ ). Porewater salinity was higher in ridges (mean $[ \pm \mathrm{SE}]=41 \pm[3]$ PSU) than in runnels (mean $[ \pm \mathrm{SE}]=35 \pm[1]$ PSU) (Table 1). However, pooled salinity and porewater $\mathrm{NH}_{4}{ }^{+}(\mathrm{n}=30)$ were inversily correlated (Fig. 5A). A salinity rise in the upper horizons of ridges is likely due to water losses through evaporation during emersed conditions. On the other hand, when the tide is in, flushing due to gravitational drainage may also induce $\mathrm{NH}_{4}{ }^{+}$losses in these horizons. Exposure to rain and wave-pumping can also alter salinity and porewater $\mathrm{NH}_{4}{ }^{+}$concentrations. Essentially, runnels represent waterlogged microenvironments in which nutrients are better retained than in the ridges.
Plots of adsorbed $\mathrm{NH}_{4}^{+}$(in 1-step or multiple-step extraction protocols) against porewater $\mathrm{NH}_{4}{ }^{+}$were not significantly correlated $(p>0.05)$, except the relationship $\mathrm{NH}_{4}{ }^{+}{ }_{\text {pw }}$ versus EDA $\mathrm{E}_{\text {rec }}$ that correlated significantly in ridges (Table 2). Some inverse correlations were found between porewater $\mathrm{NH}_{4}{ }^{+}$and the improved $K_{\mathrm{D}}$ values (Fig. 5B). Indeed, both consistency and nonconsistency in these relationships have been reported (Mackin \& Aller 1984, Simon \& Kennedy 1987). Mayer \& Rice (1992) suggest that this inverse correlation is due to saturation of high-energy sorption sites with

Table 3. Porewater $\mathrm{NH}_{4}{ }^{+}$data (mM) and calculated distribution coefficients $\left(K_{D}\right)$ using Eq. (1). Rapidly exchangeable $\mathrm{NH}_{4}^{+}\left(C_{N}^{*}\right)$ is given by the EDA ree pool. $C^{*}{ }_{N \text { to }}$ is obtained by adding the TAA pool to $\mathrm{C}^{*} \mathrm{~N}$. $\mathrm{NH}_{4}{ }^{+}$pw: porewater $\mathrm{NH}_{4}{ }^{*}$; $K_{\mathrm{D} 1}$ : data from using $\mathrm{EDA}_{\mathrm{rec}}$ in $\mathrm{Eq}$. $(1) ; K_{\mathrm{D} 2}$ : data from using $\left(\mathrm{EDA}_{\mathrm{rcr}}+\mathrm{TAA}\right)$ in Eq. (1)

\begin{tabular}{|lccr|}
\hline Section $(\mathrm{cm})$ & $\mathrm{NH}_{4}{ }^{+} \mathrm{pw}$ & $K_{\mathrm{D} 1}$ & \multicolumn{1}{c|}{$K_{\mathrm{D} 2}$} \\
\hline Ridges & & & \\
$0-1$ & $0.095 \pm 0.03$ & $1.2 \pm 0.4$ & $1.3 \pm 0.4$ \\
$1-2$ & $0.037 \pm 0.01$ & $2.9 \pm 0.9$ & $10.7 \pm 0.9$ \\
$2-3$ & $0.087 \pm 0.06$ & $2.1 \pm 1.5$ & $3.8 \pm 2.5$ \\
$3-4$ & $0.085 \pm 0.01$ & $1.9 \pm 0.3$ & $2.5 \pm 0.4$ \\
$4-5$ & $0.166 \pm 0.02$ & $1.0 \pm 0.1$ & $1.0 \pm 0.1$ \\
Runnels & & & \\
$0-1$ & $0.127 \pm 0.05$ & $2.4 \pm 0.4$ & $6.0 \pm 2.5$ \\
$1-2$ & $0.148 \pm 0.04$ & $1.3 \pm 0.3$ & $2.6 \pm 0.6$ \\
$2-3$ & $0.074 \pm 0.02$ & $4.8 \pm 1.2$ & $8.5 \pm 2.1$ \\
$3-4$ & $0.121 \pm 0.01$ & $3.7 \pm 0.4$ & $6.7 \pm 0.7$ \\
$4-5$ & $0.171 \pm 0.03$ & $3.4 \pm 0.6$ & $3.9 \pm 2.6$ \\
& & & \\
\hline
\end{tabular}



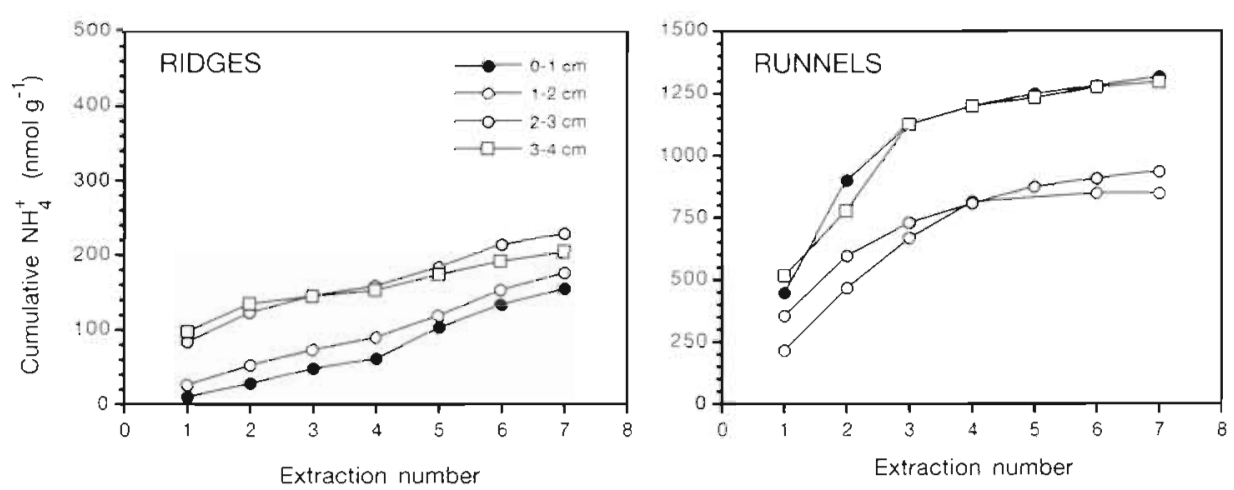

Fig. 4. Cumulative $\mathrm{NH}_{4}^{+}$content plotted against number of $\mathrm{KCl}$ extractions. The $4-5 \mathrm{~cm}$ stratum was omitted to avoid overlapping lines increasing porewater $\mathrm{NH}_{4}{ }^{+}$concentrations. We extend this explanation to complex $\mathrm{K}^{+}$effects and possibly to ion-pairing processes affecting $\mathrm{NH}_{4}^{+}$exchange.

Ridges and runnels are both silt type sediments with similar low contents of $\mathrm{C}(1.1$ and $1.3 \%)$ and $\mathrm{N}(0.2$ and $0.2 \%$ ) and similar grain sizes, but differing in $\mathrm{CaCO}_{3}$
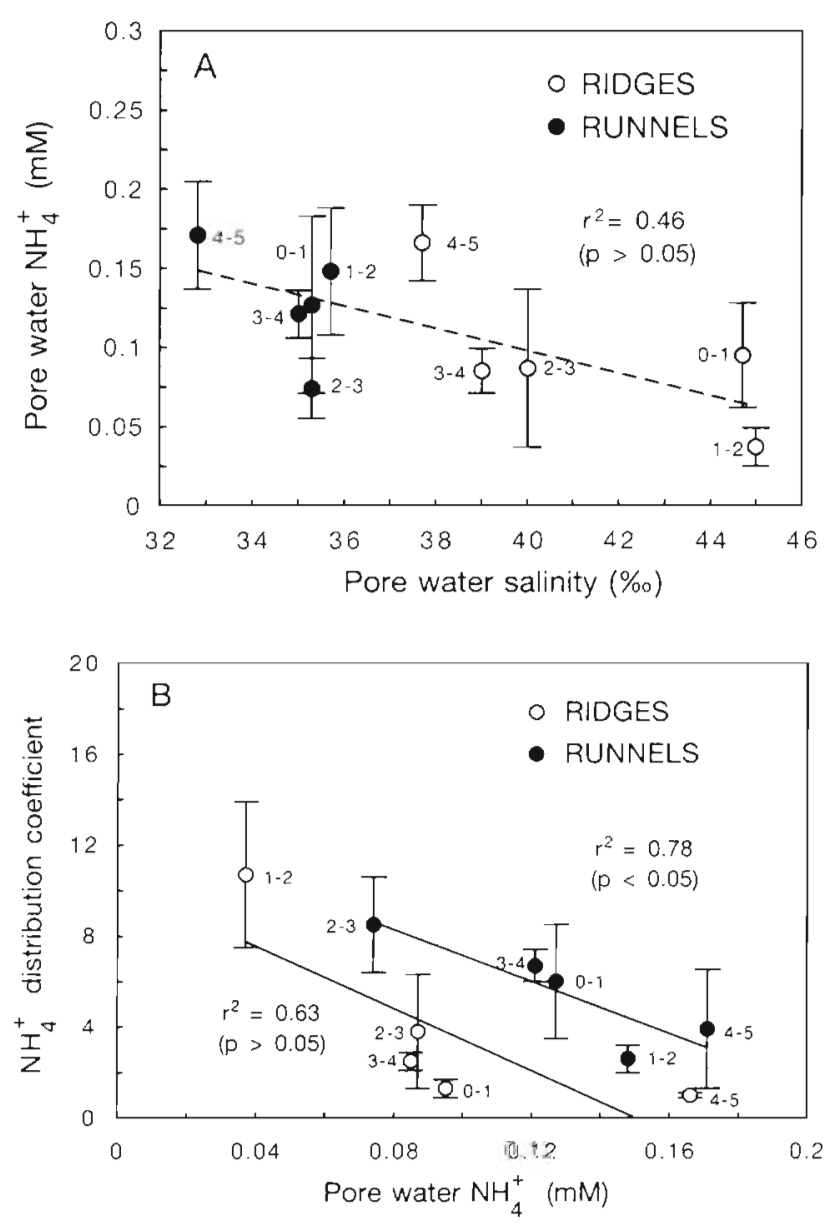

Fig. 5. (A) Relationship between porewater salinity and porewater $\mathrm{NH}_{4}{ }^{*}$ concentrations $(n=3)$ in ridges $(0)$ and runnels $(\bullet)$. Regression analysis was performed using pooled data from ridges and runnels. (B) Relationship between average $\left(\mathrm{n}=3\right.$ ) porewater $\mathrm{NH}_{4}{ }^{*}$ concentration and $K_{\mathrm{D}}$ values obtained from using $\mathrm{KCl}$ in multiple extractions content (Table 1). In ridges, grain size fractions $(<50 \mu \mathrm{m})$ did not significantly correlate with EDA $\left(\mathrm{r}^{2}=0.55, \mathrm{p}>0.05\right)$ but were inversely correlated with TAA $\left(\mathrm{r}^{2}=0.77, \mathrm{p}<0.05\right) . \mathrm{CaCO}_{3}$ did not significantly correlate with EDA rec $\left(r^{2}=0.50, p>0.05\right)$ or with TAA $\left(\mathrm{r}^{2}=0.56, \mathrm{p}>0.05\right)$. In runnels, grain size fractions $(<50 \mu \mathrm{m})$ did not correlate significantly with TAA $\left(\mathrm{r}^{2}=0.66, \mathrm{p}>0.05\right)$ or with $\mathrm{EDA}_{\mathrm{rec}}\left(\mathrm{r}^{2}=0.62, \mathrm{p}>0.05\right)$. The same was the case for $\mathrm{CaCO}_{3}$ and organic $\mathrm{N}$. These differences suggest that adsorbed $\mathrm{NH}_{4}{ }^{+}$has a different source in these structures and that organic $\mathrm{N}$ plays a minor role in the dynamic behaviour of adsorbed $\mathrm{NH}_{4}^{+}$pools.

Bioturbation effects may also account for a higher $\mathrm{NH}_{4}^{+}$yield in runnels compared to ridges. Indeed, in the $0-5 \mathrm{~cm}$ strata, Hydrobia sp. averaged 35 ind. $\mathrm{cm}^{-2}$ in runnels but only 2 ind. $\mathrm{cm}^{-2}$ in ridges, and accounted for over $90 \%$ of total fauna present in the cores. They eat benthic diatoms, so their higher populations in runnels may reflect higher sediment activity in that zone (Laima et al. unpubl.). They can thus enhance $\mathrm{NH}_{4}{ }^{+}$ regeneration and alter $\mathrm{NH}_{4}{ }^{+}$concentrations in sediment pore water by means of excretion including fecal pellets and bioturbation (Jönsson et al. 1993).

In summary, these results clearly highlight the following points:

(1) Preliminary experiments involving analysis of the reconstituted pool in 1-step extractions of ridge and runnel sediments showed that it is important to check whether current extraction techniques correctly assess the adsorbed $\mathrm{NH}_{4}{ }^{+}$pool. These data are in agreement with earlier observations that the $\mathrm{KCl}$ technique, when applied to coastal muddy sediments, should be used with caution (Laima 1994).

(2) Ridges and runnels are sedimentary structures placed side by side in the mudflat. They exhibit enormous differences with respect to $\mathrm{NH}_{4}{ }^{+}$extraction efficiency, adsorption to their particulate phases, and relationships with sediment parameters. Results clearly show that runnel bedforms contain high, multiple pools of adsorbed $\mathrm{NH}_{4}{ }^{+}$. The turnover rate of these adsorbed pools, their influence on diffusive $\mathrm{NH}_{4}{ }^{+}$ 
fluxes at the sediment-water interface, and possible influence on the $\mathrm{N}$ cycle, are unknown. Therefore, they should be the subject of further research.

(3) Spatial heterogeneity is an important issue when nutrient budgets are calculated for a particular environment. This study was restricted to the effect of 2 sedimentary structures on the spatial distribution of $\mathrm{NH}_{4}{ }^{+}$pools. As other complex sedimentary forms are present in the bay, distribution patterns of $\mathrm{NH}_{4}{ }^{+}$pools may be even more complex.

Acknowledgements. We are indebted to the Region PoitouCharentes (contract no. 96/RPC-R 115), to the Science and Technology Sub-programme of JNICT, to Lucette Joassard and Françoise Mornet (CREMA) for providing technical support, to 3 anonymous reviewers for providing a good criticism of an earlier version of the manuscript and to Conrad AubRobinson for correcting the English.

\section{LITERATURE CITED}

Berner RA (1976) Inclusion of adsorption in the modelling of early diagenesis. Earth Planet Sci Lett 29:333-340

Berner RA (1977) Stoichiometric models for nutrient regeneration in anoxic sediments. Limnol Oceanogr 22:781-786

Blackburn $T H$ (1980) Seasonal variations in the rate of organic- $\mathrm{N}$ mineralization in anoxic marine sediments. In: Daumas $R$ (ed) Biogéochimie de la matière organique à l'interface eau-sédiment marin. Centre National de Recherche Scientifique, Paris, p 173-183

Boatman CD. Murray JW (1982) Modelling exchangeable $\mathrm{NH}_{4}{ }^{+}$adsorption in marine sediments: process and control of adsorption. Limnol Oceanogr 27:99-110

Boynton WR, Kemp WM, Keefe CW (1982) A comparative analysis of nutrients and other factors influencing estuarine phytoplankton production. In: Kennedy VS (ed) Estuarine comparisons. International estuarine research conference 6. Academic Press, New York, p 69-90

Cariou-Le Gall V, Blanchard GF (1995) Monthly HPLC measurements of pigment concentration from an intertidal muddy sediment of Marennes-Oléron Bay, France. Mar Ecol Prog Ser 121:171-179

Dyer KR (1998) The morphological development of intertidal mudflats. 2nd Annual Report, European Commission. Directorate General XII, MAST III, Contract MAS 3-CT950022 Univ Plymouth

Feuillet-Girard M, Héral M, Sornin JM, Paoli MD, Robert JM, Mornet F, Razet D (1988) Éléments azotés de la colonne d'eau et de l'interface eau-sédiment du bassin de Marennes-Oléron: influence des cultures d'huitres. Aquat Living Resour 1:251-265

Feuillet-Girard M, Gouleau D, Blanchard G, Joassard L (1997) Nutrient fluxes on an intertidal mudflat in MarennesOléron Bay, influence of the emersion period. Aquat Living Resour 10:49-58

Germaneau J, Sauriau PG (1996) La mer des Pertuis: un système topographique filtrant les agents meteo-océaniques. Bull Soc Sci Nat Ouest France (nouv sér) 18:53-68

Héral M, Razet D, Deslous-Paoli JM, Berthome JP, Garnier J

Editorial responsibility: Otto Kinne (Editor),

Oldendorf/Luhe, Germany
(1983) Caractéristiques saisonnières de l'hydrobiologie du complexe estuarien de Marennes-Oléron (France). Rev Trav Inst Pêches Marit 46:97-119

Jönsson B, Sundbäck K, Nilsson P, Nilsson C, Lindström Swanberg I, Ekebom J (1993) Does the influence of the epibenthic predador Crangon crangron L. (brown shrimp) extend to sediment microalgae and bacteria. Neth $J$ Sea Res 31:83-94

Krom MD, Berner RA (1980) Adsorption of phosphate in anoxic marine sediments. Limnol Oceanogr 25:797-806

Laima MJC (1992a) Evaluation of the indophenol method to measure ammonium in extracts from coastal marine sediments. Mar Chem 39:283-296

Laima MJC (1992b) Extraction and seasonal variation of ammonium pools in different types of coastal marine sediments. Mar Ecol Prog Ser 82:75-84

Laima MJC (1992c) Recovery of ${ }^{15} \mathrm{NH}_{4}{ }^{+}$in labelling experiments on coastal marine sediments. Mar Chem 44:31-42

Laima MJC (1994) Is $\mathrm{KCl}$ a reliable extractant of ${ }^{15} \mathrm{NH}_{4}{ }^{+}$added to coastal marine sediments? Biogeochemistry 27:83-95

Mackin JE, Aller RC (1984) Ammonium adsorption in marine sediments. Limnol Oceanogr 29:250-257

Mayer LM, Rice DL (1992) Eariy diagenesis of protein: a seasonal study. Limnol Oceanogr 32:280-295

Montagna PA, Blanchard GF, Dinet A (1995) Effect of production and biomass of intertidal microphytobenthos on meiofaunal grazing rates. J Exp Mar Biol Ecol 185:149-165

Ngo TT, Pan APH, Yam CF, Leenhoff HM (1982) Interference in determination of ammonia with the hypochlorite-alkaline phenol method of Berthelot. Anal Chem 54:46-49

Nómmik H, Vahtras K (1982) Retention and fixation of ammonium and ammonia in soils: In: Stevenson FJ (ed) Nitrogen in agricultural soils. American Society of Agronomy, Madison, WI, p 123-171

Pinckney JL, Zingmark G (1993) Modelling the annual production of intertidal benthic microalgae in estuarine ecosystems. J Phycol 29:396-407

Raaphorst WV, Malschaert JFP (1996) Ammonium adsorption in superficial North Sea sediments. Cont Shelf Res 16 1415-1435

Riera P, Richard P, Grémare A, Blanchard G (1996) Food source of intertidal nematodes in the Bay of MarennesOléron (France), as determined by dual stable isotope analysis. Mar Ecol Prog Ser 142:303-309

Rosenfeld JK (1979) Ammonium adsorption in nearshore marine sediments. Limnol Oceanogr 24:356-364

Sauriau PG, Germaneau J, Morin K, Robert S (1997) Zonation scheme of bedform structure from Brouage mudflat in the Marennes-Oléron bay (Atlantic coast, France) in the morphological development of intertidal mudflats. 1st Annual Report, European Commission Directorate General XII, Mast III, Intrmud, Contract MAS 3-CT95-0022, Univ Plymouth

Seitzinger SP, Gardner WS, Spratt AK (1991) The effect of salinity on ammonium sorption in aquatic sediments: implications for benthic nutrient cycling. Estuaries 14:167-174

Simon NS, Kennedy MM (1987) The distribution of nitrogen species and adsorption of ammonium in sediments from the tidal Potomac River and Estuary. Estuar Coast Shelf Sci 25:11-26

Thorson G (1957) Bottom communities (sublittoral or shallow shelf). Treatise on marine ecology and paleoecology. Geol Soc Am Mem 67:461-534

Submitted: July 3, 1998; Accepted: January 26, 1999 Proofs received from author(s): May 20, 1999 